\title{
PENGARUH KESELAMATAN DAN KESEHATAN KERJ A TERHADAP PRESTASI KERJ A KARYAWAN PADA PT. PLN (PERSERO) APJ SEMARANG
}

\author{
Catarina Cori Pradnya Paramita \\ Administrasi Bisnis FISIP Universitas Diponegoro \\ Email: cat arina cori@yahoo.com \\ Andi Wijayanto \\ Administrasi Bisnis FISIP Universitas Diponegoro \\ Email: andi@ undip.ac.id
}

\section{Abstract}

The objective of this research is to find out the influence of Occupational Health and Safety Program toward the performance of the employees mediated by work motivation. The method of data collection in this explanatory research employs questionnaire, interview, observation, and documentation. From the population of 188 employees, the proportional stratified random sampling method results in 55 employees as the sample. Data analysis uses Path Analysis. Based on the result of the research, it can be concluded that Occupational Health and Safety Program has positive and significant influence mediated by the variable of work motivation. PT. PLN (Persero) APJ Semarang should improve its Occupational Health and Safety Program to increase employees' work motivation which in turn will result in maximum work performance.

Penelitian ini bertujuan untuk membuktikan pengaruh keselamatan dan kesehatan kerja (K3) terhadap prestasi kerja karyawan yang dimediasi variabel motivasi kerja. Teknik pengumpulan data menggunakan kuesioner, wawancara, observasi dan dokumentasi. Populasi dalam penelitian ini adalah seluruh karyawan PT. PLN (Persero) APJ Semarang yang berjumlah 118 orang. Metode pengambilan sampel menggunakan proportionate Stratified Random Sampling dan ditetapkan sampel sebanyak 55 orang. Analisis data dilakukan dengan menggunakan analisis jalur. Berdasarkan hasil penelitian, maka dapat disimpulkan bahwa keselamatan kerja dan kesejahteraan (K3) berpengaruh signifikan terhadap kinerja karyawan yang dimediasi oleh variabel motivasi kerja. PT. PLN (Persero) APJ Semarang seharusnya untuk meningkatkan K3 bagi karyawan agar motivasi kerja mereka menjadi lebih tinggi, sehingga mereka dapat memberikan performa yang maksimal.

\section{Keywords}

Occupational Health and Safety, Work Performance

Keselamatan dan Kesehatan Kerja, Prestasi Kerja

\section{PENDAHULUAN}

Setiap perusahaan didirikan untuk mencapai tujuan tertentu yang akan dicapai. Untuk mencapai tujuan tersebut diperlukan modal salah satunya adalah sumber daya manusia atau yang lebih dikenal dengan karyawan. Kemajuan perusahaan dapat dilihat dari prestasi yang diberikan oleh karyawan karena prestasi merupakan hasil dari apa yang dihasilkan karyawan apakah sesuai atau tidak dengan harapan perusahaan. Tetapi kemampuan berprestasi masing-masing karyawan berbeda-beda karena disebabkan oleh kemampuan individu, pekerjaan yang diberikan dan fasilitas yang diberikan perusahaan. Peran serta sumber daya manusia ini harus didukung dengan pengembangan peningkatan kualitas sumber daya dan pemberian motivasi.

Kebutuhan karyawan dalam melaksanakan pekerjaannya perlu mendapat perlindungan dengan adanya lingkungan kerja yang aman, nyaman dan tenteram karena akan menimbulkan keinginan untuk bekerja dengan 
baik. Semakin tersedianya fasilitas keselamatan kerja semakin sedikit kemungkinan terjadinya kecelakaan kerja. Selain keselamatan kerja, kesehatan kerja juga merupakan faktor yang penting. Kesehatan kerja yang menunjuk pada bebas dari gangguan fisik maupun mental yang dapat berasal dari lingkungan kerja. Manfaat motivasi yang utama adalah menciptakan gairah kerja karena sesuatu yang dikerjakan karena ada motivasi yang mendorongnya akan membuat orang senang mengerjakannya dan merasa dihargai. Kondisi aman dan sehat memberikan umpan balik motivasi yang akan mendorong prestasi kerja. Indrawijaya (2000) mengatakan bahwa dalam diri manusia terdapat motif berprestasi yang tercermin pada orientasi kepada tujuan dan pengabdian demi tercapainya tujuan. Prestasi bekerja merupakan tujuan perusahaan dengan didukung oleh pemberian jaminan, lingkungan, fasilitas dan motivasi kepada karyawan. Hasil penilaian prestasi kerja karyawan dapat memperbaiki keputusan personalia dan memberikan umpan balik kepada karyawan tentang pelaksanaan kerja.

Setiap tahun selalu ada karyawan yang tewas ataupun luka-luka, setiap bulan ada peningkatan karyawan yang menderita sakit dan karyawan yang tidak masuk kerja dengan alasan sakit, keperluan dinas dan cuti. Prestasi yang dihasilkan karyawan pada PT. PLN (Persero) APJ Semarang belum sesuai target yang diinginkan perusahaan. Karyawan mengharapkan adanya keselamatan dan kesehatan kerja yang lebih baik untuk dapat mendorong motivasi bekerja yang tinggi sehingga karyawan dapat meningkatkan prestasi kerja.

Apabila keselamatan dan kesehatan kerja tinggi, akan menyebabkan motivasi kerja yang tinggi sehingga dapat menghasilkan prestasi kerja yang diharapkan. Keselamatan dan kesehatan kerja yang baik, akan menimbulkan motivasi kerja yang baik juga, dengan harapan prestasi kerja karyawan tinggi. Akan tetapi dalam kenyataan dijumpai bahwa prestasi kerja karyawan masih rendah, hal ini tampak pada target yang masih belum tercapai. Berdasarkan penjelasan dapat diajukan pertanyaan penelitian sebagai berikut: (a) apakah keselamatan kerja berpengaruh signifikan terhadap motivasi kerja karyawan?; (b) apakah kesehatan kerja berpengaruh signifikan terhadap motivasi kerja karyawan?; (c) apakah keselamatan dan kesehatan kerja secara simultan berpengaruh signifikan terhadap motivasi kerja karyawan?; (d) apakah keselamatan kerja secara langsung berpengaruh signifikan terhadap prestasi kerja karyawan?; (e) apakah motivasi kerja berpengaruh signifikan terhadap prestasi kerja karyawan?; (f) apakah kesehatan kerja secara langsung berpengaruh signifikan terhadap prestasi kerja karyawan?; (g) bagaimanakah pengaruh keselamatan kerja dan kesehatan kerja terhadap prestasi kerja karyawan yang dimediasi variabel motivasi kerja?.

\section{KAJ IAN TEORI}

Keselamatan kerja adalah membuat kondisi kerja yang aman dengan dilengkapi alat-alat pengaman, penerangan yang baik, menjaga lantai dan tangga bebas dari air, minyak, nyamuk dan memelihara fasilitas air yang baik (Agus, 1989). Keselamatan kerja menunjuk pada perlindungan kesejahteraan fisik dengan tujuan mencegah terjadinya kecelakaan atau cedera terkait dengan pekerjaan (Malthis dan Jackson, 2002).

Menurut Suma'mur (1993), tujuan dari keselamatan kerja adalah: (a) Setiap pegawai dapat jaminan keselamatan dan kesehatan kerja; (b) Agar setiap perlengkapan dan peralatan kerja digunakan sebaik-baiknya; (c) Agar semua hasil produksi dipelihara keamanannya; (d) Agar adanya jaminan atas pemeliharaan dan peningkatan gizi pegawai; (e) Agar meningkat kegairahan, keserasian kerja dan partisipasi kerja; (f) Terhindar dari gangguan kesehatan yang disebabkan lingkungan kerja; dan (g) Agar pegawai merasa aman dan terlindungi dalam bekerja.

Kecelakaan kerja adalah setiap perbuatan atau kondisi tidak selamat yang dapat mengakibatkan kecelakaan. Faktor yang dilakukan perusahaan untuk mencegah kecelakaan (Silalahi, 1995) adalah: (a) Faktor subtitusi yaitu penggantian bahan yang berbahaya; (b) Pengendalian teknis termasuk 
ventilasi, penerangan dan perlengkapan; (c) Penyempurnaan ergonomic (penyesuaian dengan bentuk alat dan bahan yang tersedia); (d) Pengawasan atas kebiasaan; (e) Penyesuaian volume produksi dengan jam proses kerja; dan Adanya Panitia Keselamatan dan Kesehatan Kerja dalam perusahaan.

Keselamatan merupakan hirarki kebutuhan dari Maslow (Gibson, et. Al., 1994) yang mana apabila kebutuhan terpenuhi maka termotivasi untuk melakukan pekerjaan sesuai harapan perusahaan.

Kesehatan kerja adalah kondisi bebas dari gangguan fisik, mental, emosi atau rasa sakit yang disebabkan lingkungan kerja (Mangkunegara, 2001). Perusahaan mengenal dua kategori penyakit yang diderita tenaga kerja (Silalahi, 1995) yaitu: (a) Penyakit umum yang mungkin dapat diderita semua orang. Penyakit umum merupakan tanggung jawab anggota masyarakat karena itu harus mengadakan pemeriksaan sebelum masuk kerja; dan (b) Penyakit akibat kerja, yang dapat timbul setelah karyawan yang tadinya terbukti sehatmemulai pekerjaannya.

Pencegahan gangguan kesehatan akibat faktor dalam pekerjaan (Suma'mur, 1993) adalah dengan substitusi, ventilasi, isolasi, pelindung, pemeriksaan kesehatan sebelum kerja, pemeriksaan berkala, penerangan, dan pendidikan tentang kesehatan kepada pekerja secara kontinyu. Pemantauan kesehatan kerja dapat dilakukan dengan (Rivai, 2003) mengurangi timbulnya penyakit, penyimpanan catatan tentang lingkungan kerja, memantau kontak langsung, penyaringan genetik. Menurut peraturan Menteri Tenaga Kerja dan Transmigrasi Republik Indonesia, kesehatan kerja bertujuan untuk memberi bantuan kepada tenaga kerja, melindungi tenaga kerja dari gangguan kesehatan yang timbul dari pekerjaan dan lingkungan kerja, meningkatkan kesehatan, memberi pengobatan dan perawatan serta rehabilitas.

Motif diartikan sebagai sebab yang menjadi dorongan tindakan seseorang, dasar pikiran dan pendapat, sesuatu yang menjadi pokok (Arep dan Tanjung, 2003). Sedangkan menurut Manullang (1992) motivasi berarti pemberian tenaga pendorong yang mendorong manusia untuk bertindak atau tenaga dalam diri manusia yang menyebabkan manusia bertindak.

Motivasi muncul karena adanya kebutuhan yaitu kekurangan yang dialami individu pada suatu waktu tertentu yang dapat berupa fisik, psikologis atau sosiologis. Bila ada kebutuhan, individu lebih mudah termotivasi. Teori atau model yang menjelaskan motivasi (Gibson, et.al, 1994) salah satunya adalah hirarki kebutuhan dari Maslow. Inti teorinya adalah bahwa kebutuhan manusia tersusun dalam suatu hirarki yaitu: (a) Fisiologis: kebutuhan makan, minum, tempat tinggal dan bebas dari sakit; (b) Keselamatan dan kesehatan: kebebasan dari ancaman; (c) Rasa memiliki, social, dan cinta : teman, afiliasi, interaksi dan cinta; (d) Penghargaan: penghargaan diri, penghargaan dari orang lain; dan (e) Aktualisasi diri: memenuhi diri sendiri dengan penggunaan kemampuan maksimum, ketrampilan dan potensi.

Teori Maslow mengasumsikan bahwa orang berusaha memenuhi kebutuhan yang lebih pokok sebelum berusaha memenuhi kebutuhan yang tertinggi. Arep dan Tanjung (2003) menyebutkan motivasi yang diinginkan karyawan adalah jaminan ketenangan dan ketegangan terhadap diri dan keluarga pegawai, kondisi lingkungan kerja baik fisik maupun non fisik, dan jaminan kebebasan dalam menjalankan pekerjaannya.

Prestasi kerja juga diartikan sebagai sesuatu yang dikerjakan yang dihasilkan atau diberikan seseorang atau sekelompok orang (Dharma, 1991). Prestasi kerja merupakan suatu hasil kerja yang dicapai seseorang dalam melaksanakan tugas-tugas yang dibebankan kepadanya didasarkan atas kecakapan, pengalaman, kesungguhan, serta waktu (Hasibuan, 2005). Prestasi kerja timbul dari dalam diri pekerja karena prestasi kerja merupakan gabungan dari kemampuan dan minat pekerja, kemampuan peran dan tingkat motivasi pekerja.

Menurut Rasimin (1987), faktor yang dapat mempengaruhi prestasi kerja yaitu faktor yang bersumber dari individu misalnya bakat, kepribadian, sifat, gairah, pendidikan, pengalaman, usia dan faktor yang berasal dari luar individu yang berhubungan dengan jabatan, lingkungan dan organisasi. Untuk 
mengetahui prestasi yang telah dihasilkan karyawan dibutuhkan penilaian terhadap prestasi kerja karyawan. Metode penilaian kerja menurut Umar (1998) adalah: (a) Metode penilaian berorientasi waktu lalu. Penilaian prestasi kerja dinilai berdasarkan hasil yang telah dicapai selama ini; dan (b) Metode penilaian berorientasi masa depan yang memusatkan prestasi kerja di waktu yang akan datang melalui penilaian potensi karyawan atau melalui penetapan sarana prestasi di masa datang.

Tujuan penilaian prestasi adalah memperbaiki dan meningkatkan prestasi kerja karyawan yang pada akhirnya nanti akan bermanfaat bagi pelaksanaan fungsi-fungsi operasional SDM (Panggabean, 2002). Selain itu, kegunaan-kegunaan prestasi kerja (Handoko, 1995) diantaranya: (a) Perbaikan Prestasi Kerja. Umpan balik pelaksanaan kerja memungkinkan karyawan, manajer dan departemen personalia dapat memperbaiki kegiatan-kegiatan mereka demi perbaikan prestasi kerja; (b) Ketidakakuratan informasional. Prestasi kerja yang jelek mungkin menunjukkan kesalahan-kesalahan dalam informasi analisis jabatan, rencanarencana sumber daya manusia, atau komponen-komponen sistem informasi manajemen personalia lainnya. Menggantungkan diri pada informasi yang tidak akurat (teliti) dapat mengakibatkan keputusan personalia yang diambil menjadi tidak tepat; (c) Kesalahan-kesalahan desain pekerjaan. Prestasi kerja yang jelek mungkin merupakan suatu tanda kesalahan dalam desain pekerjaan.
Penilaian prestasi dapat membantu diagnosa kesalahan-kesalahan tersebut; (d) Tantangantantangan eksternal. Kadang-kadang prestasi kerja dipengaruhi oleh faktor-faktor di luar lingkungan kerja, seperti keluarga, kesehatan, kondisi financial atau masalah pribadi. Dengan penilaian prestasi kerja tersebut, departemen personalia dimungkinkan menawarkan bantuan kepada semua karyawan yang dibutuhkan atau yang diperkirakan memerlukan.

Berdasarkan uraian tersebut di atas, maka dapat disusun hipotesis sebagai berikut:

$\mathrm{H}_{1}$ : Keselamatan kerja berpengaruh signifikan terhadap motivasi kerja karyawan.

$\mathrm{H}_{2}$ : Kesehatan kerja berpengaruh signifikan terhadap motivasi kerja karyawan.

$\mathrm{H}_{3}$ : Keselamatan dan kesehatan kerja secara simultan berpengaruh signifikan terhadap motivasi kerja karyawan.

$\mathrm{H}_{4}$ : Keselamatan kerja secara langsung berpengaruh signifikan terhadap prestasi kerja karyawan.

$\mathrm{H}_{5}$ : Motivasi kerja berpengaruh signifikan terhadap prestasi kerja karyawan

$\mathrm{H}_{6}$ : Kesehatan kerja secara langsung berpengaruh signifikan terhadap prestasi kerja karyawan.

$\mathrm{H}_{7}$ : Keselamatan kerja dan kesehatan kerja terhadap prestasi kerja karyawan yang dimediasi variabel motivasi kerja.

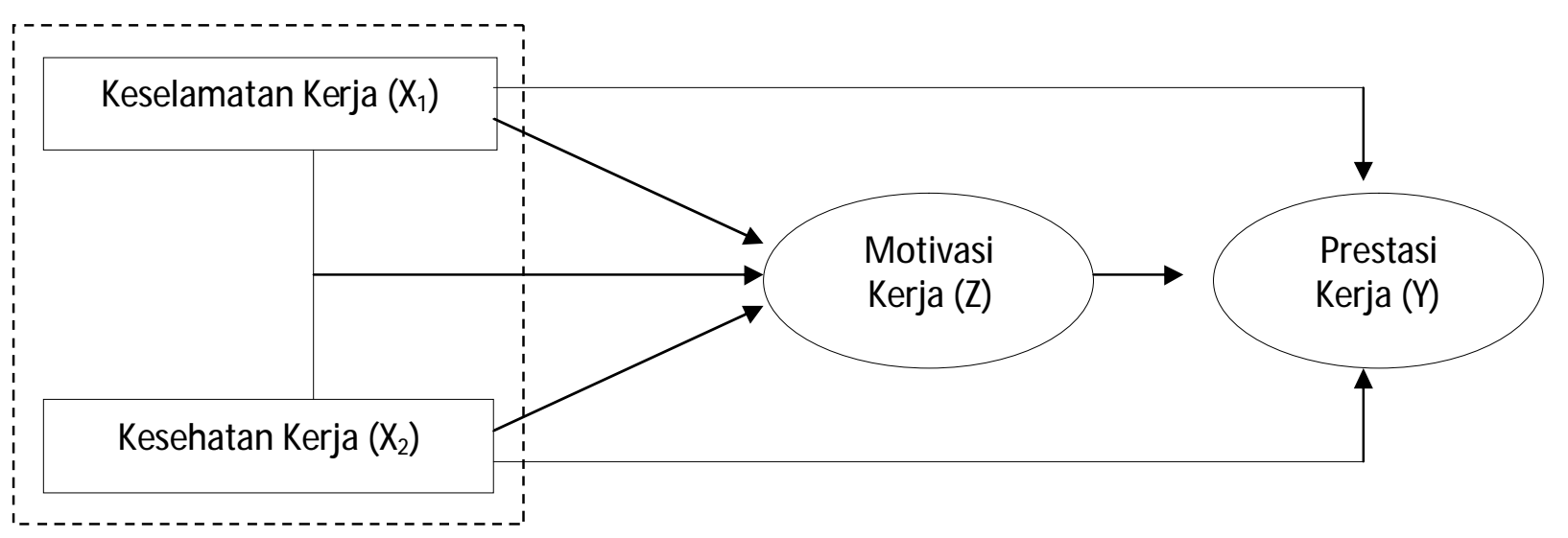

Gambar 1. Kerangka Pemikiran Hipotesis 
Hipotesis-hipotesis tersebut di atas secara ringkas ditunjukkan dalam Gambar 1.

Variabel keselamatan kerja diukur dari tingkat pemahaman terhadap pemakaian alat keselamatan yang benar, tingkat pendidikan dan pelatihan terhadap keselamatan, tingkat pengendalian administrasi dan personil, jaminan kes elamatan, dan tingkat kelengkapan alat keselamatan kerja. Variabel kesehatan kerja diukur dengan indikator tingkat kesehatan secara periodik, jaminan kesehatan yang diberikan perusahaan, dan tingkat kelengkapan fasilitas kerja yang mendukung kesehatan. Indikator motivasi kerja adalah tingkat rasa aman dalam melaksanakan pekerjaan, peluang untuk mengembangkan kemampuan dan keahlian, frekuensi kehadiran, dan ketepatan waktu kehadiran. Sedangkan indikator prestasi adalah ketepatan waktu dalam melaksanakan pekerjaan, kuantitas pekerjaan yang bisa diselesaikan, dan jumlah kesalahan melakukan pekerjaan.

\section{METODE}

Tipe penelitian ini adalah Explanatory research atau penelitian penjelasan karena dalam penelitian ini akan dijelaskan mengenai pengaruh antara keselamatan dankesehatan kerja serta motivasi kerja terhadap prestasi kerja karyawan pada PT. PLN (Persero) APJ Semarang. Populasi dalam penelitian ini adalah seluruh karyawan PT. PLN (Persero) APJ Semarang yang berjumlah 118 orang. Metode pengambilan sampel menggunakan proportionate Stratified Random Sampling. Perhitungan sampel dalam penelitian ini menggunakan rumus Slovin:

$\mathrm{n}=\frac{\mathrm{N}}{1+\mathrm{Ne}^{2}}$

dimana $\mathrm{N}$ adalah ukuran populasi, $\mathrm{n}$ adalah ukuran sampel, dan e adalah persen kelonggaran ketidaktelitian karena kesalahan pengambilan sampel yang masih dapat ditolerir atau diinginkan (10\%). Berdasarkan rumus Slovin, maka dapat dihitung banyaknya sampel sebagai berikut:

$$
\begin{aligned}
& n=\frac{118}{1+118(0,1)^{2}} \\
& n=54,12 \text { (dibulatkan menjadi 55) }
\end{aligned}
$$

Dengan demikian, sesuai dengan rumus tersebut maka sampel dalam penelitian ini adalah sebanyak 55 orang.

Sumber data berasal dari data primer dan data sekunder. Teknik pengumpulan data menggunakan kuesioner, wawancara, observasi dan dokumentasi. Data diolah melalui tahapan editing, scoring, dan tabulating.

Analisis data dilakukan dengan menggunakan analisis regresi linier sederhana, regresi linier berganda dan Path Analysis. Berdasarkan hasil analisis maka dilakukan uji $t$ untuk menguji pengaruh parsial variabel bebas terhadap variabel terikat dan uji $\mathrm{F}$ untuk menguji pengaruh variabel bebas terhadap variabel terikat secara semultan. Sedangkan analisis jalur dilakukan untuk menguji pengaruh variabel bebas terhadap variabel terikat melalui variabel intervening.

HASIL

Keselamatan kerja adalah keselamatan yang bertalian dengan mesin, pesawat, alat kerja, bahan dan proses pengolahannya, landasan tempat kerja dan lingkungannya serta cara-cara melakukan pekerjaan (Suma'mur, 1993). Sebagian besar responden (49,09\%) menyatakan keselamatan kerja yang dilakukan PT. PLN (Persero) APJ Semarang adalah sangat baik. Artinya, tingkat pemahaman terhadap pemakaian alat keselamatan yang benar, tingkat pendidikan dan pelatihan terhadap keselamatan, tingkat pengendalian administrasi dan personil, tingkat jaminan keselamatan, dan tingkat kelengkapan alat perlindungan diri yang dilakukan perusahaan dirasakan karyawan sangat baik. Sedangkan sebanyak $12,73 \%$ berpendapat keselamatan kerja tidak baik karena ada responden kurang mengetahui keselamatan kerja dalam kantor.

Kesehatan mengupayakan agar yang sehat tetap sehat dan bukan sekedar mengobati, merawat atau menyembuhkan gangguan kesehatan atau penyakit. Persepsi responden terhadap kesehatan kerja akan diketahui dari 3 item pertanyaan meliputi pemberian perhatian kesehatan secara periodik, jaminan kesehatan kerja dan fasilitas kesehatan. Mayoritas responden (56,36\%) menyatakan fasilitas kesehatan kerja adalah sangat baik. Hal ini berarti bahwa pemeliharaan kesehatan secara 
periodik, jaminan kesehatan dan fasilitas kesehatan yang disediakan perusahaan sangat mendukung karyawan untuk melaksanakan pekerjaan masing-masing.

Sedangkan penilaian responden mengenai motivasi kerja mereka dapat diketahui dari pemenuhan kebutuhan rasa aman dalam melaksanakan pekerjaan, pemenuhan kebutuhan untuk mengembangkan kemampuan dan keahlian, frekuensi kehadiran, dan ketepatan waktu datang bekerja. Sebagian besar responden yaitu 31 responden $(56,36 \%)$ motivasi kerja yang dimiliki sangat tinggi dan 18 responden $(32,73 \%)$ memiliki motivasi kerja tinggi karena kebutuhannya terpenuhi oleh perusahaan yakni pemenuhan akan kebutuhan rasa aman dan pemenuhan mengembangkan kemampuan dan keahlian. Sehingga apabila kebutuhan tersebut terpenuhi maka karyawan memiliki dorongan untuk bekerja lebih baik. Selain itu, adanya frekuensi kehadiran dan ketepatan waktu menunjukkan motivasi melaksanakan pekerjaan dengan baik.

Prestasi kerja disebutkan sebagai hasil kerja secara kualitas dan kuantitas yang dicapai oleh seorang karyawan dalam melaksanakan tugasnya sesuai dengan tanggung jawab yang diberikan kepadanya (Mangkunegara, 2001). Persepsi karyawan mengenai prestasi yang dihasilkan berbeda-beda karena setiap individu memiliki karater yang tidak sama. Untuk mengukur prestasi kerja karyawan, diajukan 3 pertanyaan yaitu mengenai ketepatan waktu, kuantitas pekerjaan dan kualitas pekerjaan. Hanya sedikit responden $(10,91 \%)$ yang menyatakan prestasi kerjanya tidak baik. Sedangkan sebanyak 30,91\% responden menghasilkan prestasi kerja yang baik. Mayoritas responden $(58,18 \%)$ menyatakan prestasi kerja yang dihasilkan sangat baik. Prestasi kerja yang sangat baik ini ditunjukkan dari ketepatan waktu melakukan pekerjaan, kuantitas pekerjaan dan meminimalisir kesalahan melakukan pekerjaan Oleh karena itu, pekerjaan dipandang sebagai sesuatu yang menyenangkan.

Hasil pengujian menunjukkan nilai thitung sebesar 7,693 dengan signifikasi sebesar 0,000 kurang dari 0,05 (5\%) dan thitung lebih besar dari $t_{\text {tabel }}(\mathrm{df}=\mathrm{n}-2, \mathrm{df}=55-2=53)$ yaitu 1,674 maka dapat diartikan bahwa $\mathrm{Ho}$ ditolak, dan $\mathrm{Ha}$ diterima. Dengan kata lain ada pengaruh positif dan signifikan antara keselamatan kerja terhadap motivasi kerja. Korelasi antara variabel keselamatan kerja dengan variabel motivasi kerja sebesar 0,726 maka hubungan linier antara keselamatan kerja $\left(X_{1}\right)$ dengan motivasi kerja ( $Z$ ) adalah kuat dan positif. Pengaruh yang diberikan variabel keselamatan kerja terhadap variabel motivasi kerja sebesar $52,8 \%$ sedangkan sisanya sebesar $47,2 \%$ dapat dipengaruhi faktor lain selain faktor keselamatan kerja.

Hasil pengujian menunjukkan nilai thitung sebesar 7,663 dengan signifikasi sebesar 0,000 kurang dari 0,05 (5\%) dan thitung lebih besar dari $t_{\text {tabel }}(\mathrm{df}=\mathrm{n}-2, \mathrm{df}=55-2=53)$ (Supranto, 2009) yaitu 1,674 maka Ho ditolak, dan Ha diterima. Dengan kata lain ada pengaruh positif dan signifikan antara kesehatan kerja terhadap motivasi kerja. Tingkat keeratan hubungan variabel kesehatan kerja dengan motivasi kerja sebesar 0,725. Pengaruh yang diberikan variabel kesehatan kerja terhadap variabel motivasi kerja sebesar $52,6 \%$ sedangkan sisanya sebesar 47,4\% dipengaruhi faktor lain selain faktor kesehatan kerja.

Hasil pengujian menunjukkan nilai $F_{\text {hitung }}$ sebesar 37,292 dengan signifikasi 0,000 artinya kurang dari 0,05 (5\%) dan degree of freedom $\left(\mathrm{df}_{1}\right)$ pembilang/numerator $(\mathrm{m})$ yaitu banyaknya variabel bebas $\left(X_{1}, X_{2}\right)=2$, dan $\mathrm{df}_{2} /$ atau $\mathrm{df}$ denominator $(n-m-1)=55-2-1=52$ sehingga diperoleh $F_{\text {hitung }}$ lebih besar dari $F_{\text {tabel }}$ yaitu 3,175 maka dapat diartikan bahwa Ho di tolak, dan $\mathrm{Ha}$ diterima. Dengan kata lain ada pengaruh signifikan antara keselamatan dan kesehatan kerja secara bersama-sama terhadap motivasi kerja. Korelasi antara variabel keselamatan dan kesehatan kerja dengan variabel motivasi kerja sebesar 0,768. Pengaruh yang diberikan variabel keselamatan dan kesehatan kerja terhadap variabel motivasi kerja sebesar $58,9 \%$ sedangkan sisanya sebesar $41,1 \%$ dipengaruhi faktor lain selain faktor keselamatan dan kesehatan kerja.

Persamaan regresi linier sederhana dibentuk $Y=2,468+0,450 X_{1}$, dimana $Y=$ Prestasi Kerja,$X_{1}=$ Keselamatan Kerja. Tingkat keeratan hubungan variabel keselamatan kerja 
dengan prestasi kerja sebesar 0,787 maka hubungan linier antara keselamatan kerja $\left(X_{1}\right)$ dengan prestasi kerja $(Y)$ adalah sangat kuat dan positif. Pengaruh yang diberikan variabel keselamatan kerja terhadap variabel prestasi kerja sebesar $62 \%$ sedangkan sisanya sebesar $38 \%$ dipengaruhi faktor lain selain faktor keselamatan kerja. Nilai thitung sebesar 9,298 dengan signifikasi sebesar 0,000 kurang dari $0,05(5 \%)$ dan thitung lebih besar dari tabel $(\mathrm{df}=\mathrm{n}$ 2, df= 55-2=53) (Supranto, 2009) yaitu 1,674 maka dapat diartikan bahwa $\mathrm{Ho}$ ditolak, dan $\mathrm{Ha}$ diterima. Dengan kata lain ada pengaruh positif dan signifikan antara keselamatan kerja terhadap prestasi kerja.

Persamaan regresi linier sederhana dibentuk $Y=2,925+0,520 Z$ dimana $Y=$ Prestasi Kerja dan Z = Motivasi Kerja. Korelasi antara variabel motivasi kerja dengan variabel prestasi kerja adalah sebesar 0,743 maka hubungan linier antara motivasi kerja (Z) dengan prestasi kerja $(\mathrm{Y})$ adalah kuat dan positif. Pengaruh yang diberikan variabel motivasi kerja terhadap variabel prestasi kerja sebesar $55,2 \%$ sedangkan sisanya sebesar $44,8 \%$ dipengaruhi faktor lain selain faktor motivasi kerja. Nilai thitung sebesar 8,087 dengan signifikasi sebesar 0,000 kurang dari 0,05 (5\%) dan thitung lebih besar dari tabel $(\mathrm{df}=\mathrm{n}-2, \mathrm{df}=55$ 2=53) (Supranto, 2009) yaitu 1,674 maka dapat diartikan bahwa Ho ditolak, dan Ha diterima. Dengan kata lain ada pengaruh positif dan signifikan antara motivasi kerja terhadap prestasi kerja.

Persamaan regresi linier sederhana dibentuk $Y=2,216+0,761 X_{2}$ dimana $Y=$ Prestasi Kerja dan $X_{2}=$ Kesehatan Kerja. Tingkat keeratan hubungan variabel kesehatan kerja dengan prestasi kerja sebesar 0,786 maka hubungan linier antara kesehatan kerja $\left(\mathrm{X}_{2}\right)$ dengan prestasi kerja $(\mathrm{Y})$ adalah sangat kuat dan positif. Pengaruh yang diberikan variabel kesehatan kerja terhadap variabel prestasi kerja sebesar $61,8 \%$ sedangkan sisanya sebesar $38,2 \%$ dipengaruhi faktor lain selain faktor kesehatan kerja. Nilai thitungsebesar 9,250 dengan signifikasi sebesar 0,000 kurang dari $0,05(5 \%)$ dan $t_{\text {hitung }}$ lebih besar dari tabel $(\mathrm{df}=\mathrm{n}-2, \mathrm{df}=55-2=53$ ) (Supranto, 2009) yaitu 1,674 maka dapat diartikan bahwa Ho ditolak, dan $\mathrm{Ha}$ diterima. Dengan kata lain ada pengaruh positif dan signifikan antara kesehatan kerja terhadap prestasi kerja.

Berdasarkan analisis jalur (Path Analysis), dapat diketahui bahwa: (a) Pengaruh variabel keselamatan kerja terhadap motivasi kerja sebesar 0,409; (b) Pengaruh variabel kesehatan kerja terhadap motivasi kerja sebesar 0,403; (c) Pengaruh variabel keselamatan kerja terhadap prestasi kerja sebesar 0,340; (d) Pengaruh variabel motivasi kerja terhadap prestasi kerja sebesar 0,254; (e) Pengaruh variabel kesehatan kerja terhadap prestasi kerja sebesar 0,334.

Sedangkan secara tidak langsung, pengaruh variabel keselamatan kerja terhadap prestasi kerja melalui motivasi kerja adalah $(0,409 \times 0,254)=0,103886$. sementara itu pengaruh variabel kesehatan kerja terhadap prestasi kerja melalui motivasi kerja adalah $(0,403 \times 0,254)=0,102362$.

Pengaruh total variabel keselamatan kerja terhadap prestasi kerja melalui motivasi kerja adalah sebesar $(0,409+0,254)=0,663$. Sedangkan pengaruh total variabel kesehatan kerja terhadap prestasi kerja melalui motivasi kerja $=(0,403+0,254)=657$. Berdasarkan hasil analisis data, maka dapat disusun persamaan struktural sebagai berikut:

$$
\begin{aligned}
& Z=0,409 X_{1}+0,403 X_{2}+\delta_{1} \\
& Y=0,340 X_{1}+0,334 X_{2}+0,254 Z+\delta_{2}
\end{aligned}
$$

Pengaruh variabel keselamatan kerja, dan kesehatan kerja terhadap motivasi kerja sebesar 0,589. Pengaruh variabel lain di luar model terhadap motivasi kerja sebesar 0,411. Pengaruh variabel keselamatan kerja, kesehatan kerja dan motivasi kerja terhadap prestasi kerja secara gabungan sebesar 0,719. Pengaruh variabel lain di luar model terhadap prestasi kerja sebesar 0,281.

\section{PEMBAHASAN}

Keselamatan kerja adalah usaha menciptakan kondisi aman bagi pekerja dengan memberikan perlindungan di lingkungan kerja supaya pekerja merasa nyaman dalam melaksanakan pekerjaannya. Rasa aman dalam bekerja merupakan hal yang sangat vital bagi pekerja untuk memperbaharui motivasi dalam melaksanakan pekerjaan (Rachmawati, 2007). Hasil penelitian memperlihatkan bahwa secara umum karyawan sangat paham 
terhadap pemakaian alat keselamatan meskipun ada karyawan yang tidak paham karena merasa perusahaan kurang memberikan pendidikan pemakaian alat keselamatan yang benar. Mayoritas karyawan juga berpendapat bahwa pendidikan dan pelatihan terhadap keselamatan sudah baik karena adanya organisasi keselamatan kerja yang bertanggung jawab menyelenggarakan pelatihan tersebut. Adanya pemberian pengendalian administrasi dan personil yang menurut sebagian besar karyawan sudah baik juga turut mendukung motivasi bekerja meskipun ada juga yang menyatakan tidak baik. Selain itu karyawan juga merasa bahwa jaminan keselamatan yang diberikan perusahaan sudah sangat baik karena adanya tindak lanjut apabila karyawan mengalami kecelakaan kerja. Alat perlindungan diri yang disediakan perusahaan juga sudah lengkap karena perusahaan sudah melengkapi dan menguji kebutuhan jumlah minimumnya. Maka dapat disimpulkan bahwa keselamatan kerja karyawan pada PT. PLN (Persero) APJ Semarang sangat baik sehingga berdampak pada motivasi kerja yang dapat dilihat dari hasil adanya pengaruh positif dan signifikan antara keselamatan kerja terhadap motivasi kerja.

Selain keselamatan kerja, kesehatan kerja juga berperan dalam meningkatkan motivasi kerja karena apabila kesehatan kerja tidak terpenuhi maka karyawan tidak merasa sejahtera dan apabila kesejahteraan buruk maka tidak memiliki motivasi dalam bekerja (Racmawati, 2007). Kesehatan kerja adalah spesialisasi dari ilmu-ilmu kesehatan atau kedokteran beserta prakteknya yang bertujuan agar pekerja atau masyarakat pekerja memperoleh derajat kesehatan setinggitingginya baik fisik maupun mental dan sosial dengan usaha preventif dan kuratif terhadap penyakit-penyakit gangguan kesehatan yang diakibatkan faktor-faktor pekerjaaan dan lingkungan kerja serta terhadap penyakit umum. Untuk menghasilkan motivasi kerja yang tinggi, kesehatan kerja di PT. PLN (Persero) APJ Semarang dapat dilihat dari pemberian perhatian kesehatan secara periodik, adanya jaminan kesehatan dan fasilitas kesehatan.
Menurut sebagian besar karyawan, pemberian perhatian kesehatan secara periodik sudah baik dengan diadakannya kegiatankegiatan seperti medical check up, dan senam pagi untuk menjaga kesehatan karyawan. Selain itu, sangat terjaminnya kesehatan kerja misalnya adanya biaya penggantian untuk berobat maupun rawat inap bagi karyawan dan keluarganya membuat karyawan memiliki motivasi ketika melaksanakan pekerjaan. Kelengkapan fasilitas kesehatan yang dirasakan karyawan juga turut mendukung tingginya motivasi kerja karyawan. Dalam penelitian ini, ditemukan bahwa kesehatan kerja karyawan sangat baik sehingga menghasilkan pengaruh positif dan signifikan antara kesehatan kerja dan motivasi kerja. Hasil ini sesuai dengan teori Maslow tentang hirarki kebutuhan manusia yaitu teori kepuasan yang mana bebas dari sakit merupakan kebutuhan fisiologis atau kebutuhan pokok yang manusia penuhi sebelum berusaha memenuhi kebutuhan yang lebih tinggi.

Keselamatan dan kesehatan kerja bagi karyawan merupakan tujuan yang ingin dicapai oleh perusahaan untuk menunjang kerja karyawan. Pengetahuan tentang keselamatan dan kesehatan kerja yang maju akan dicapai baik dan realistik merupakan faktor yang sangat penting dalam memberikan kegairahan dalam bekerja (Ranupandojo dan Husnan, 1998). Menurut penelitian yang dilakukan Johan (Rukhviyanti, 2007), Sistem Manajemen Keselamatan dan Kesehatan Kerja (SMK3) akan meningkatkan pengaruh yang signifikan terhadap motivasi. Demikian juga dengan penelitian Hendarman (Rukhviyanti, 2007) juga menunjukkan pengaruh positif program SMK3 terhadap motivasi. Oleh karena itu, hasil penelitian ini juga menunjukkan ada pengaruh positif dan signifikan keselamatan dan kesehatan kerja secara bersama-sama terhadap motivasi kerja dimana variabel kesehatan kerja memiliki pengaruh yang lebih besar daripada variabel keselamatan kerja. Sebagian besar karyawan menilai kesehatan kerja sangat baik yang dapat diketahui dari baiknya pemberian perhatian terhadap kesehatan secara periodik, sangat terjaminnya 
kesehatan karyawan dan fasilitas kesehatan yang lengkap.

Banyak pengusaha yang menganggap keselamatan kerja kurang bermanfaat, hal ini memberikan sikap kurangnya perhatian pengusaha sehingga dapat berdampak pada turunnya prestasi kerja karena karyawan merasa kurang nyaman dalam bekerja. Agar prestasi karyawan sesuai dengan harapan perusahaan maka dapat memperhatikan pemahaman pemakaian alat keselamatan kerja yang benar, pendidikan dan pelatihan keselamatan, pemberian pengendalian administrasi dan personil, jaminan keselamatan dan kelengkapan alat perlindungan diri. Mayoritas karyawan menyatakan keselamatan kerja sangat baik karena adanya perhatian perusahaan tentang pemakaian alat keselamatan yang baik, pendidikan keselamatan bagi karyawan pada saat training maupun telah menjadi karyawan, prosedur kerja yang jelas, menyediakan pelindung diri seperti helm, sepatu, tangga, dan tabung pemadam kebakaran. Oleh karena itu maka dihasilkan ada pengaruh positif dan signifikan antara keselamatan kerja terhadap prestasi kerja. Hasil ini juga ditemukan dalam penelitian oleh Saputro (2007) yang mengatakan bahwa jaminan keselamatan kerja memberikan pengaruh positif terhadap prestasi kerja dan Sudarmanta (2007) bahwa keselamatan kerja memiliki pengaruh yang signifikan terhadap prestasi kerja.

Sebagian individu sudah memiliki dorongan untuk menyelesaikan pekerjaan dengan baik. Kegairahan dalam bekerja dapat meningkatkan produksi, mempertinggi mutu pekerjaan. Bukti paling dasar terhadap keberhasilan motivasi adalah hasil yang diperoleh pelaksanaan pekerjaan (Ranupandojo dan Husnan, 1998). Motivasi karyawan di PT. PLN (Persero) APJ Semarang dapat dilihat dari sebagian besar karyawan menyatakan setuju bahwa adanya pemenuhan kebutuhan rasa aman dalam melaksanakan pekerjaan misalnya dengan tersedianya parkir untuk kendaraan karyawan yang dijaga oleh satpam. Juga pernyataan setuju mayoritas karyawan terhadap pemenuhan kebutuhan untuk mengembangkan kemampuan dan keahlian. Alasannya karena sering diadakannya pelatihan bagi karyawan dan kesempatan untuk menduduki posisi yang berbeda jika prestasinya baik. Selain itu frekuensi kehadiran yang baik oleh karyawanmenunjukkan bahwa karyawan jarang absen dari tempat kerja karena lingkungan kerja yang baik dan nyaman. Karyawan juga memiliki ketepatan waktu datang bekerja karena jam yang ditetapkan perusahaan merupakan jam yang biasa digunakan untuk masuk jam kantor.

Dari alasan-alasan tersebut maka motivasi kerja karyawan sebagian besar sangat tinggi, maka dihasilkan pengaruh positif dan signifikan antara motivasi kerja terhadap prestasi kerja. Hasil ini sesuai dengan teori bahwa orang yang termotivasi ada perasaan untuk meraih prestasi yang baik dan manfaat orang yang termotivasi adalah pekerjaan dapat diselesaikan dengan tepat (Arep dan Tanjung, 2003).

Kesegaran jasmani dan rohani merupakan faktor penunjang seseorang untuk bekerja. Kondisi mental seseorang sangat mempengaruhi prestasi kerja (Ranupandojo dan Husnan, 1998). Kesehatan kerja karyawan dapat diamati dari baiknya pemberian perhatian kesehatan secara periodik yang menurut karyawan baik karena adanya pencegahan penyakit akibat kerja dengan pemeriksaan berkala, sangat terjaminnya kesehatan alasannya apabila karyawan menderita sakit tidak perlu melalui asuransi kesehatan jadi prosesnya tidak terlalu lama. Selain itu, fasilitas kesehatan yang tersedia sudah lengkap seperti toilet yang terjaga kebersihannya. Dari hal-hal tersebut maka diperoleh bahwa kesehatan kerja karyawan sangat baik sehingga mempengaruhi prestasi kerja karyawan. Maka didapat bahwa ada pengaruh positif dan signifikan antara kesehatan kerja terhadap prestasi kerja. Hasil ini juga ditemukan dalam penelitian yang dilakukan oleh Saputro (2007) yang mengatakan bahwa jaminan kesehatan kerja memberikan pengaruh positif terhadap prestasi kerja; Sudarmanta (2007) bahwa kesehatan kerja memiliki pengaruh yang signifikan terhadap prestasi kerja; serta Kriscawati (2007) jika kesehatan kerja dikelola dengan baik oleh perusahaan maka prestasi kerja karyawan akan meningkat. 


\section{KESIMPULAN DAN SARAN}

Berdasarkan hasil penelitian, maka dapat ditarik beberapa kesimpulan sebagai berikut: (a) Keselamatan kerja berpengaruh positif dan signifikan terhadap motivasi kerja karyawan pada PT. PLN (Persero) APJ Semarang. Besar pengaruh yang diberikan variabel keselamatan kerja terhadap motivasi kerja 52,8\%; (b) Kesehatan kerja berpengaruh positif dan signifikan terhadap motivasi kerja karyawan pada PT. PLN (Persero) APJ Semarang. Besar pengaruh yang diberikan variabel kesehatan kerja terhadap motivasi kerja 52,6\%; (c) Keselamatan dan kesehatan kerja berpengaruh signifikan terhadap motivasi kerja karyawan pada PT. PLN (Persero) APJ Semarang. Besar pengaruh yang diberikan variabel keselamatan dan kesehatan kerja terhadap motivasi kerja 58,9\%; (d) Keselamatan kerja berpengaruh positif dan signifikan terhadap prestasi kerja karyawan pada PT. PLN (Persero) APJ Semarang. Besar pengaruh yang diberikan variabel keselamatan kerja terhadap prestasi kerja 62\%; (e) Motivasi kerja berpengaruh positif dan signifikan terhadap prestasi kerja karyawan pada PT. PLN (Persero) APJ Semarang. Besar pengaruh yang diberikan variabel motivasi kerja terhadap prestasi kerja 55,2\%; (f) Kesehatan kerja berpengaruh positif dan signifikan terhadap prestasi kerja karyawan pada PT. PLN (Persero) APJ Semarang. Besar pengaruh yang diberikan variabel kesehatan kerja terhadap prestasi kerja 61,8\%; (g) Variabel yang memiliki pengaruh paling besar adalah variabel keselamatan kerja terhadap prestasi kerja karena jika perusahaan memberikan keselamatan kerja yang baik kepada karyawan maka karyawan merasa aman dan nyaman dalam bekerja terutama bagi karyawan lapangan yang pekerjaannya lebih mengandung bahaya, misalnya karyawan teknik yang harus siap apabila ada pemadaman dan konsleting. Alat perlindungan diri seperti helm, sepatu, tangga, tali pengaman sangat diperlukan untuk menjamin keselamatan karyawan.

Peneliti menyarankan perlu adanya standardisasi alat pelindung diri, seperti tali, sepatu, helm, tabung pemadam dibutuhkan kontrol yang baik oleh perusahaan apakah terpakai dengan baik dan layak digunakan. Juga pengetahuan dini terhadap risiko pekerjaan misalnya jika ada gempa atau kebakaran. Kesehatan karyawan perlu mendapat perhatian supaya karyawan tidak menderita penyakit akibat kerja misalnya dengan membangun smoking area di dalam kantor jadi bagi karyawan yang tidak merokok bebas dari asap rokok apalagi untuk karyawan yang sedang mengandung. Perusahaan juga perlu mengusahakan memberikan motivasi yang lebih baik kepada karyawan dengan pemberian kebutuhan fisiologis mulai dari gaji, jaminan kesehatan, jaminan hari tua/pensiun, interaksi dengan pengaturan ruang kerja yang nyaman dengan rekan kerja dan pemindahan karyawan sehingga tidak merasa bosan dengan lingkungan kerja. Perusahaan perlu memberikan rasa aman bagi karyawan yang bekerja dengan menyediakan lahan parkir yang lebih luas.

\section{DAFTAR REFERENSI}

Agus, Tulus. 1989. Manajemen Sumber Daya Manusia. Jakarta: PT. Gramedia Pustaka.

Arep, Ishak dan Hendri Tanjung. 2003. Manajemen Motivasi. Jakarta: PT. Gramedia Widiasarana Indonesia.

Dharma, Agus. 1991. Manajemen Prestasi Kerja. Jakarta : Rajawali Pers.

Gibson, J.L., Ivancevich, J.M., Donnely, J.M. 1994. Organisasi dan Manajemen. Jakarta: Erlangga.

Handoko, T. Hani. 1995. Manajemen Personalia dan Sumber daya Manusia. Yogyakarta : BPFE.

Hasibuan, Malayu SP. 2005. Manajemen Sumber Daya Manusia. Jakarta: Bumi Aksara.

Indrawijaya, Adam. 2000. Perilaku Organisasi. Bandung: Algensi.

Kriscawati, lin. 2007. Pengaruh Kesehatan Kerja Terhadap Prestasi Kerja Karyawan Pada CV. Sami jaya Cirebon. 
http://dspace.widyatama.ac.id/handle/103 64/972. diunduh 15 Juni 2010.

Malthis, Robert dan Jackson. 2002. Manajemen Sumber Daya Manusia. Jakarta: Salemba 4.

Mangkunegara, A.A. Anwar Prabu. 2001. Manajemen Sumber Daya Manusia Perusahaan. Bandung: Rosda.

Manullang. 1992. Dasar-Dasar Manajemen. Jakarta: Ghalia Indonesia.

Panggabean, Mutiara S. 2002. Manajemen Sumber Daya Manusia. Bogor: Ghalia Indonesia.

Rachmawati, Ike Kusdyah. 2007. Manajemen Sumber Daya Manusia. Yogyakarta: Andi.

Ranupandojo, Heidjrachman dan Suad Husnan. 1998. Manajemen Personalia. Yogyakarta: BPFE.

Rasimin, B.S. 1987. Paper Khusus Manajemen Keuangan Kerjasama PJ KA dan PDAM. Yogyakarta: FE Gama.

Rivai, Veitzal. 2003. Manajemen Sumber Daya Manusia untuk Perusahaan. Jakarta : Murai Kencana.

Rukhviyanti, Novi. 2007. Pengaruh Keselamatan dan Kesehatan Kerja terhadap Kinerja Karyawan melalui Motivasi pada Perusahaan Garmen di
Kawasan Industri Ranaekeh.www.Stanim.ac.id. diunduh 15 Juni 2010.

Saputro, Ari. 2008. Pengaruh Kesehatan, Keselamatan Kerja, Upah Dan Tunjangan Kesejahteraan Terhadap Peningkatan Prestasi Kerja Karyawan Pada PT. Perkebunan Nusantara IX (Persero) Batu Jamus Arum Di Karanganyar. http://etd.eprints.ums.ac.id 12654l. Diunduh tanggal 15 Juni 2010.

Silalahi, Bennet. 1995. Manajemen Kesehatan dan Keselamatan Kerja. Jakarta: Pustaka Binaman.

Sudarmanta, Agus. 2007. Pengaruh Program Keselamatan dan Kesehatan Kerja terhadap Prestasi Karyawan pada Perusahaan Industri Kulit Surya Magetan. http://digilib.umm.ac.id/gdl. php?. Diunduh 15 Juni 2010.

Suma'mur. 1993. Higiene Perusahaan dan Kesehatan Kerja. Jakarta: Gunung Agung.

Supranto, J. 2009. Statistik Teori dan Aplikasi. Jakarta: Erlangga.

Umar, Hussein. 1998. Riset Sumber Daya Manusia dalam Organisasi. Jakarta: PT. Gramedia Pustaka Utama.

2005. Pedoman Kes elamatan dan Kesehatan Kerja di Lingkungan PT. PLN (Persero). Jakarta: PT. PLN (Persero). 